\title{
COMENTARII PRIVIND UTILIZAREA SISTEMELOR TERMOSOLARE ACTUALE LA CLIMATIZAREA SPAȚIILOR ÎN CLĂDIRI ${ }^{1}$
}

\author{
LITERATURE REVIEW ON THERMO SOLAR AIR \\ COLLECTORS FOR CONDITIONING OF SPACE IN \\ BUILDINGS $S^{2}$
}

conf. dr. ing./assoc. prof. PhD. eng. Sanda Budea, prof. dr. ing./prof. PhD. eng. Viorel Bădescu, prof. dr. ing./prof. PhD. eng. Adrian Ciocănea, as. dr. ing./as. PhD. eng. Iuliana Şoriga

Universitatea Politehnică din Bucureşti

University Politehnica of Bucharest

sanda.budea@upb.ro

\footnotetext{
${ }^{1}$ Articol publicat ca urmare a finanțării PN-III-P2-2.1-PED-2016-1154, contract 83PED/2017

${ }^{2}$ This article is being published as the result of project UEFISCDI contract 83 PED/2017, PN-III-P2-2.1-PED2016-1154
} 


\title{
Rezumat
}

Noile tehnologii de încălzire sau răcire cu energie solară a aerului sunt dezvoltate astfel încât să integreze colectoarele solare în anvelopa clădirii. Multe dintre aceste tehnologii colectează energie solară pentru a produce atât căldură, cât și energie electrică. Lucrarea de față trece în revistă câteva soluții constructive, testate până în prezent, pentru colectoare solare de aer - cu geam pe colector, fără geam sau cu perforații prin materialul care absoarbe radiația solară. Lucrarea analizează performanțele acestor sisteme tinând seama de poziționarea colectoarelor, orientarea pe verticală sau orizontală a canalelor de curgere a aerului, efectul multiplelor parcurgeri ale aerului prin materialul absorbant etc. De asemenea, a fost urmărită influența vântului și integrarea arhitecturală a colectoarelor utilizate la încălzirea sau răcirea clădirilor rezidenţiale, de birouri sau industriale.

Stocarea mai eficientă a căldurii și păstrarea performanțelor un timp mai lung țin cont de soluțiile tehnologice utilizate la realizarea colectoarelor și, mai nou, de utilizarea materialelor cu schimbare de fază (phase change materials - PCM), în construcția sistemelor termo-solare aferente. În cercetările și aplicațiile actuale o pondere tot mai mare o au soluțiile hibride solare termice și fotovoltaice, modificarea performanțele acestora fiind de asemenea evidențiată în articol.

Autorii trec în revistă și soluții software dedicate analizei curgerii și evaluării performanțelor colectoarelor solare de aer, cum ar fi TCFLOW- software pentru analiza curgerii în colectoare termice, TRNSYS - pachet de programe de simulare bazat pe trasfer de călduă, CFD Fluent sau COMSOL - abreviere de la COMmon SOLution - ambele sunt aplicații de analiză și simulări cu elemente finite a proceselor fizice complexe.

Cuvinte cheie: colectoare de aer cald, colectoare perforate, materiale cu schimbare de fază, sisteme hibride termosolare - fotovoltaice

\begin{abstract}
New solar air heating or cooling technologies are developed to integrate solar collectors into the building envelope. Many of these technologies collect solar energy to produce both heat and electricity. This paper reviews some constructive solutions tested until now for solar air collectors - glazed or unglazed collectors, or transpired through absorber material of solar collectors. The paper analyzes the performances of these systems considering the position of the collectors, the vertical or horizontal orientation of the air flow channels, the effect of the multiple air passages through the absorber material etc. The influence of wind and the architectural integration of collectors used for heating or cooling of residential, office or industrial buildings were also studied.

Better storage of heat and keeping performance for a longer time considers the technological solutions used to make the collectors and, more recently, the use of phase change materials PCM, in the construction of solar thermal systems.In current research and applications, hybrid thermo-solar and photovoltaic systems have a growing share, and their performance improving are also highlighted in the article.

The authors also review the software solutions dedicated to analyzing the flow and performance assessment of solar collectors such as TCFLOW-software to analyze the air flow in solar collector, TRNSYS-simulation software package based on heat transfer, computer fluid dynamic CFD Fluent or COMSOL - COMmon SOLution abbreviation, both are finite element analysis and simulations of complex physical processes.
\end{abstract}

Keywords: solar air collector, transpired collector, phase change materials, hybrid thermo-solar and photovoltaic 


\section{Introducere - Obiective}

Lucrarea își propune să treacă în revistă tehnologiile testate până în prezent, de colectare a energiei solare pentru încălzirea sau răcirea aerului în clădiri. Sunt prezentate soluții pentru colectoare solare de aer: acoperite cu geam, neacoperite sau cu perforații.

Lucrarea analizează performanțele acestor sisteme considerând: aerului:

a) poziția colectoarelor, orientarea verticală sau orizontală a canalelor de curgere a b) efectul trecerilor multiple de aer prin materialul absorbant, (http://solarwall.com/en/products/solarwall-air-heating/solarwall-2-stage.php)

c) materialul absorbant al colectorului solar (metal sau polimer), (Badache M. 2013),

d) influența vântului,

e) influența radiației solare (Fleck B. A., 2002), (Badache M. 2013),

f) integrarea arhitecturală a colectorilor (http://solarwall.com/en/products/solarwall-airheating/solarwall-2-stage.php).

Aceste tipuri de colectoare pot fi utilizate pentru încălzirea sau răcirea clădirilor rezidențiale, de birouri sau industriale. Încălzirea spațiului pentru aplicații rezidențiale și comerciale se poate face prin utilizarea panourilor solare de aer cald. Acestea funcționează prin absorbția aerului din interiorul clădirii sau din mediul exterior și trecerea acestuia prin colectorul solar; aerul se încălzește prin conducție din materialul absorbant și apoi este trimis în spațiul de locuit sau de lucru prin mijloace pasive sau cu ajutorul unui ventilator. Încă din 1945 George Löf, a construit un sistem solar de aer cald pentru o casă din Boulder, Colorado.

Sistemele cu colectoare solare de aer asigură atât încălzirea cât și ventilarea spațiului.

Articolul integrează cercetările autorilor asupra colectoarelor termo-solare de aer în realizările la nivel mondial, arată eficiența utilizării sistemelor hibride termo-solare şi fotovoltaice, identifică aspecte legate de integrarea colectoarelor în clădiri, și nu în ultimul rând prezintă utilizarea materialelor cu schimbare de fază în stocarea mai bună a microclimatului clădirilor.

Autorii cercetează teoretic şi experimental un colector solar de aer cu perforații, cu materiale cu schimbare de fază, în cadrul unui proiect cu finanțare națională.

\section{Clasificări, tehnologie} astfel:

Colectoarele termo-solare de aer, din punct de vedere al tehnologiilor, pot fi clasificate

a) după suprafața exterioară, expusă la soare, în:

- cu geam transparent şi cu izolarea părților laterale şi spatelui colectorului pentru minimizarea pierderilor de căldură în mediul ambient. Colectoarele moderne au un coeficient de absorbție a căldurii de peste $93 \%$

(https://en.wikipedia.org/wiki/Solar_thermal_collector\#Solar_thermal_collector s_heating_air).

- fără geam - sunt bune pentru aplicații industriale, dar sunt afectate de condițiile meteorologice și de depunerea prafului.

b) după metodele de dirijare a aerului sunt de trei tipuri:

- colectoare cu multiple treceri prin materialul absorbant (through-pass collectors) - oferă cea mai mare eficiență a oricărei tehnologii solare, aerul trece printr-un material perforat și se încălzește din proprietățile conductive ale materialului și din proprietățile convective ale aerului în mișcare. Aceste colectoare au cea mai mare suprafață, ceea ce 


\section{Introduction - Objectives}

This paper aims to review the technologies tested so far to collect solar energy for heating or cooling the air in buildings. Solutions for solar air collectors: glazed, unglazed, or transpired solar collectors are presented.

The paper analyses the performances of these systems considering:

a) the position of the collectors, the vertical or horizontal orientation of the air flow channels; b) the effect of the multiple air passages through the absorber material, (http://solarwall.com/en/products/solarwall-air-heating/solarwall-2-stage.php)

c) the absorber material of solar collector (metal or polymer), (Badache M. 2013),

d) the influence of the wind,

e) the influence of the solar irradiance (FleckB. A., 2002), (Badache M. 2013),

f) the architectural integration of collectors (http://solarwall.com/en/products/solarwall-airheating/solarwall-2-stage.php).

These types of collectors can be used for heating or cooling of residential, office or industrial buildings. Space heating for residential and commercial applications can be done through the use of solar air heating panels. These operate by drawing air from the building envelope or from the outdoor environment and passing it through the collector; the air warms by conduction from the absorber and is then supplied to the living or working space by either passive means or with the aid of a fan. Since 1945, George Löf has built a solar heated air system for a house in Boulder, Colorado.

Systems with solar air collector asses also space heating and ventilating.

The article integrates the authors researches on the thermo-solar collectors of air in global achievements, shows the efficiency of the use of solar thermal and photovoltaic hybrid systems, identifies issues related to the integration of collectors in buildings, and finally presents the use of phase-change materials in better storage of building microclimate.

The authors investigate theoretically and experimentally a solar collector with perforations- transpired collectors, with phase-changing materials, within a project with national funding.

\section{Classifications, technology}

Thermal-solar air collectors can be classified considering technologies:

a) after the outer surface, exposed to the sun, in:

- glazed -with a transparent sheet and insulated side and back panels to minimize heat loss to ambient air. The absorber plates in modern panels can have absorptivity of more than $93 \%$

- (https://en.wikipedia.org/wiki/Solar_thermal_collector\#Solar_thermal_collectors_heat ing_air).

- unglazed - are good for industrial applications, but the system is influenced by meteorological conditions and dust.

b) according by their air-ducting methods there are three types:

- through-pass collectorsoffer the highest efficiency of any air solar technology, air passes through a perforated material and is heated from the conductive properties of the material and the convective properties of the moving air. Through-pass collectors have 
permite o rată relativ ridicată de transfer de căldură. Ca dezavantaj - scade semnificativ variația presiunii și necesită o putere mai mare a ventilatorului pentru evacuarea aerului cald.

- colectoare cu trecerea aerului prin caneluri verticale sau orizontale pe fața (front-pass) ( http://www.fao.org/docrep/t1838e/T1838E0v.htm) (Shukla A.et al. 2012),

- pe spatele panourilor (back-pass) (Shukla A.et al. 2012),

- combinate (Shukla A.et al. 2012),

(http://rimstar.org/renewnrg/solar_air_heater_types_diy_homemade.htm).

În configurațiile de trecere prin față, prin spate și combinate, aerul este dirijat prin fața, prin spatele, sau prin ambele părți ale absorbantului, pentru a fi încălzit și întors în clădire. Deși trecerea aerului pe ambele părți ale absorbantului asigură o suprafaţă mai mare pentru transferul de căldură conductiv, problemele cu praful pot să apară din trecerea aerului pe partea frontală a absorbantului, ceea ce limitează cantitatea de lumină solară primită și reduce eficiența absorbantului.

În zonele cu climă rece, sunt mai bune colectoarele solare acoperite cu geam, datorită faptului că păstrează mai bine căldura și au o întreținere mai ușoară.

Colectoarele fără geam au fost monitorizate pe scară largă de „Natural Resources Canada", care a dezvoltat instrumentul de fezabilitate RETScreen TM pentru a modela economia de energie obținută cu colectoarele solare compacte sau perforate. Sistemele termo-solare fără geam au fost instalate într-o varietate de aplicații pentru clădiri comerciale, industriale, de instituții, agricole și de proces, în țări din întreaga lume.

Odată cu creșterea ponderii sistemelor de energie regenerabilă pentru clădiri, colectoarele solare de aer, fără geam sunt acum utilizate pentru ansambluri de clădiri, datorită producției de energie ridicată, cu eficiență de până la $90 \%$, în comparație cu energia solară fotovoltaică și termică de apă caldă (http://stonehavenlife.com/comparing-solar-air-heater-designsperformance/), cu eficiență mai redusă.

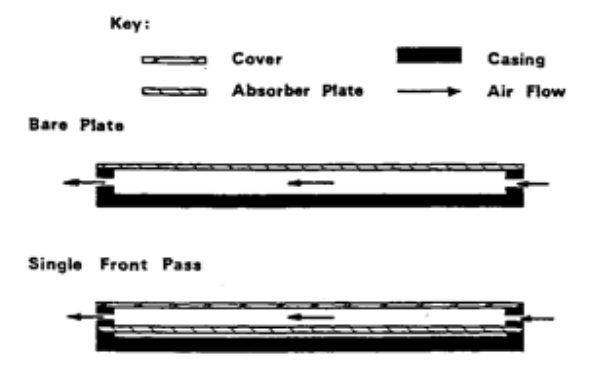

Cel mai recent studiat și utilizat tip de colector de aer fără geam este cel perforat. În România, astfel de colectoare perforate au fost foarte puțin studiate teoretic. Proiectul la care autorii lucrează în prezent deschide în acest fel perspectiva aprofundării acestor cercetări teoretice și experimentale.

Diferite soluții constructive de colectoare termo solare de aer se pot vedea în Fig. 1,2,3, cu trecerea aerului prin fața, prin spatele absorbantului, cu una sau
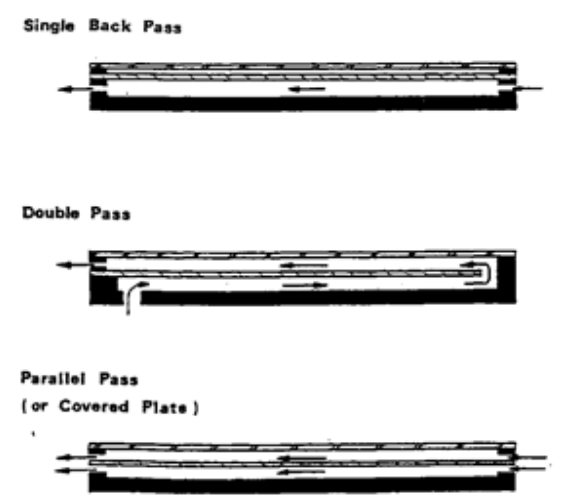
mai multe treceri, cu geam, cu unul sau două geamuri de acoperire, fără geam compacte sau perforate.

Alte soluții constructive includ aripioare longitudinale sau șicane, ca în Fig. 4 (Foued Chabane s.o. 2013, Badache M. 2013). Canalele de curgere pot fi verticale sau orizontale, în cel de-al doilea caz rezultând mai multe treceri ale aerului și o mai bună performanță.

Fig. 1: Colector solar cu geam, trecere prin faţă sau prin spate, simplă sau dublă

Glazed solar air collector front or back, single or double pass (http://www.fao.org/docrep/t1838e/T1838E0v.htm) 
the most surface area which enables relatively high conductive heat transfer rates. Asdisadvantage, significant pressure drop that can require greater fan power.

- front-pass collectors (http://www.fao.org/docrep/t1838e/T1838E0v.htm) (Shukla A.et al. 2012).

- back pass (Shukla A.et al. 2012)

- combination between front and back pass collectors (Shukla A.et al. 2012), (http://rimstar.org/renewnrg/solar air heater types diy homemade.htm).

In front-pass, back-pass and combination type configurations the air is directed on either the front, theback, or on both sides of the absorber to be heated and returnedinside the building. By passing the air on both sides of the absorber is provide a greater surface area for conductive heat transfer.Issues with dust (fouling) can arise from passing air on the front side of the absorber which limits the amount of sunlight received and reduces the absorber efficiency.

In cold climates zones, glazed air solar collectors are better, since its keeps the heat better and have a lighter maintenance.

The unglazed air collector most common type on the market are the transpired solar collector. The technology has been extensively monitored by Natural Resources Canada, who has developed the feasibility tool RETScreen ${ }^{\mathrm{TM}}$ to model the energy savings from compact or transpired solar collectors. Unglazed and transpired systems have been installed in a variety of commercial buildings, industrial, public buildings, also in agricultural and process applications in countries around the world.

With the increasing in the share of renewable energy systems on buildings, unglazed thermal collectors are now used across the entire building stock due to high energy production, high solar conversion (up to 90\%), comparedwith solar photovoltaic and solar water heating, with lower efficiency (http://stonehavenlife.com/comparing-solar-air-heater-designsperformance/).

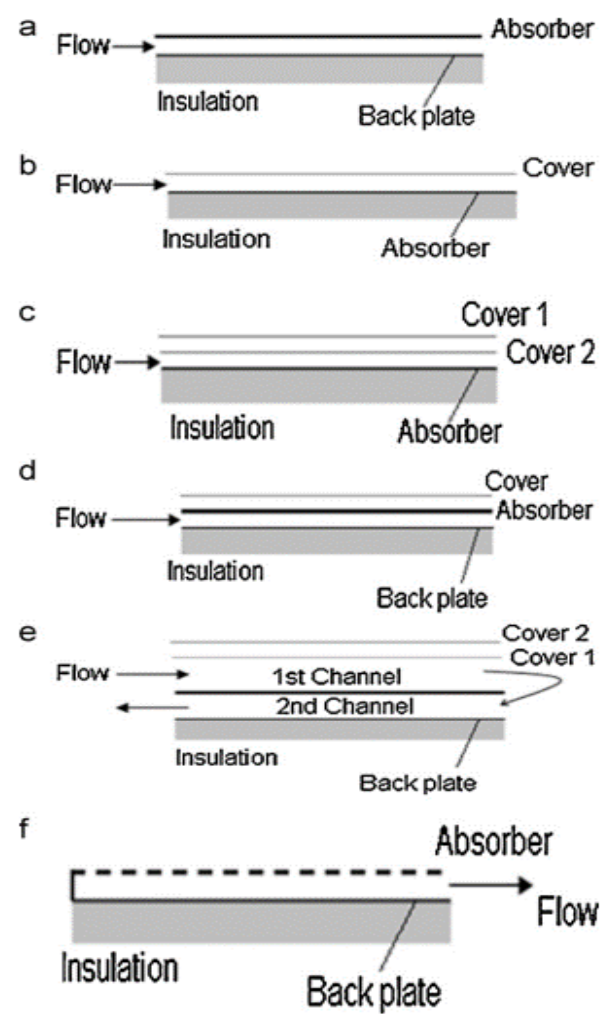

The most recently studied and used type of unglazed air collector is the transpired one. In Romania, such collectors have been very little theoretically studied. The project to which authors currently work, opens in this way, the prospect of deepening their theoretical and experimental research.

Different constructive solutions of thermo-solar air collectors can be seen in Fig. 1, 2, 3, with front or back, single or double pass, glazed, unglazed or transpired, with one or two covers.

Other constructive solutions include longitudinal fins or baffles, as in Fig.4 (Foued Chabaneet.al. 2013, Badache M. 2013). The flow channels can also be vertical or horizontal, in the second case resulting multiple passages of the air and a better performance.

Fig. 2: Colector solar de aer acoperit cu unul sau două geamuri sau perforat (f) (Shukla A.et al. 2012)

Different solar air collector, single or double cover,glazed or transpired (f) 


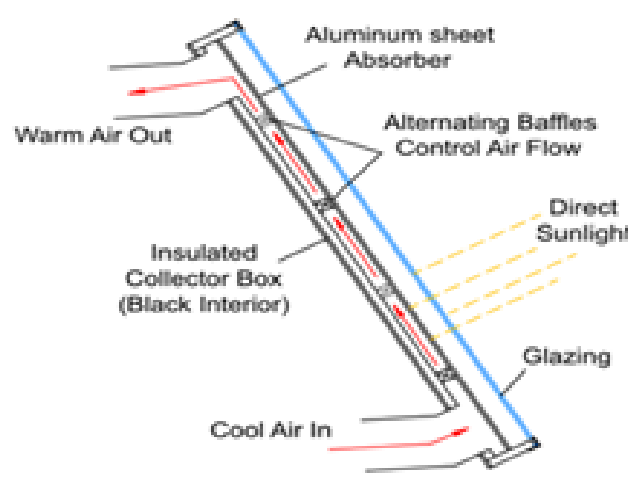

Back-pass Solar Air Collector

a)

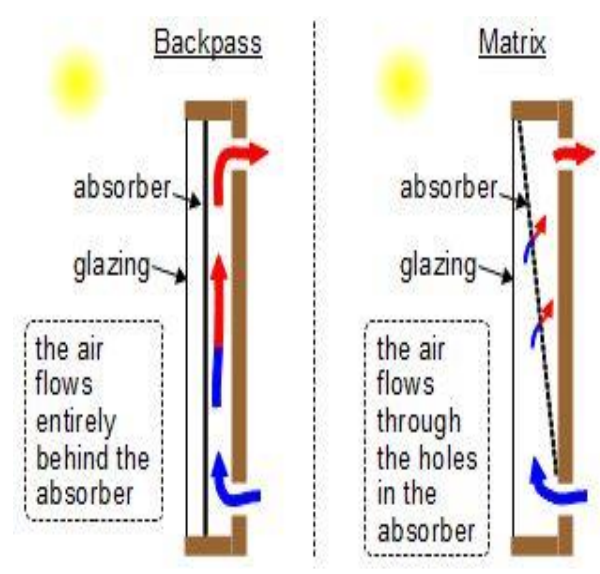

b)

Fig. 3: Colector solar cu geam, cu trecere a aerului prin spateı absorbantuluı a) sau prın pertorațı b)

Glazed solar air collector with back pass, single or double pass, the air flows behind a) or through the holes of the absorber b)

(http://stonehavenlife.com/comparing-solar-air-heater-designs-performance/, http://rimstar.org/renewnrg/solar_air_heater_types_diy_homemade.htm)
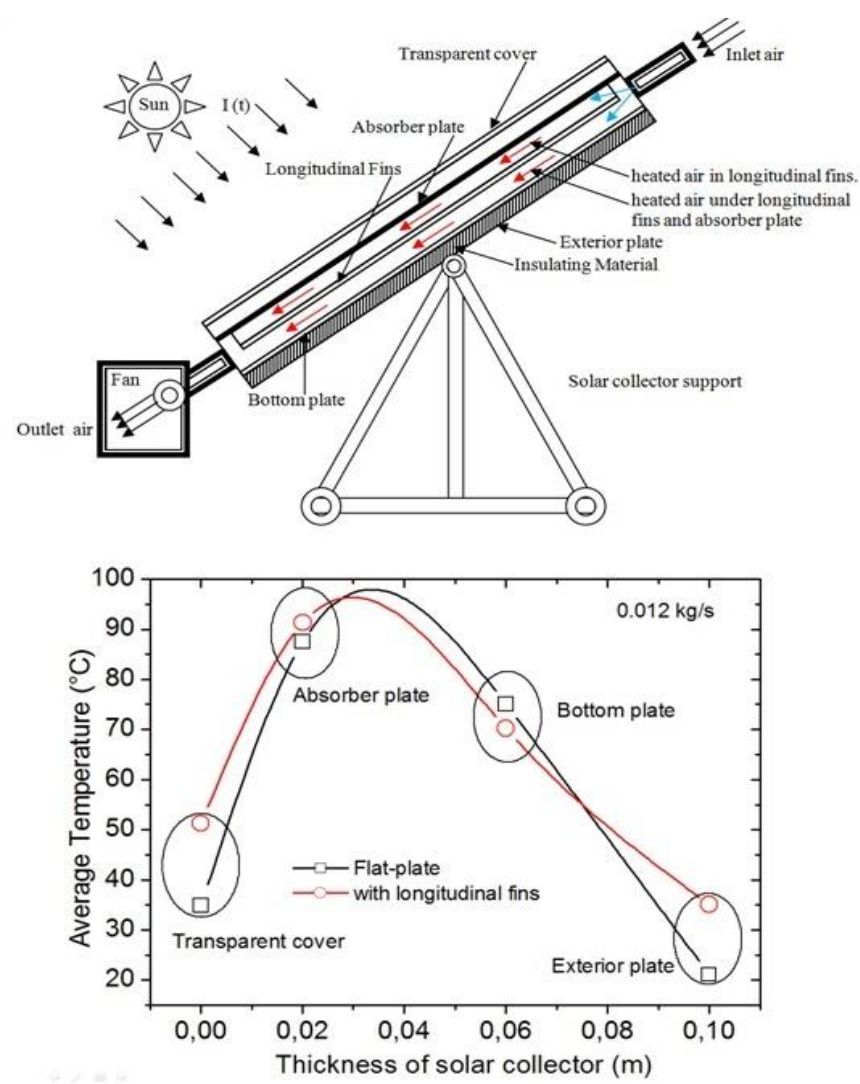

view facing gable
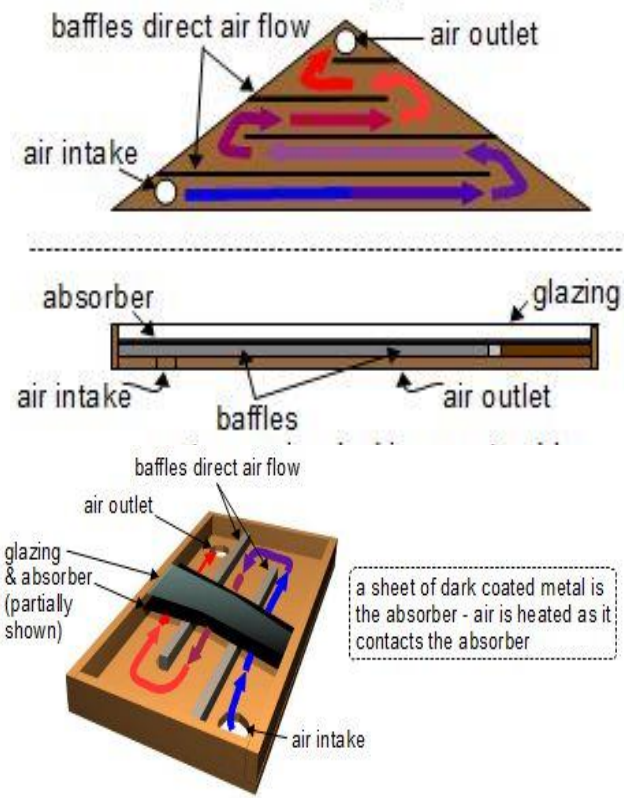

Fig. 4: Colector solar de aer cald cu aripioare sau șicane, verticale sau orizontale (Foued Chabane s.o. 2013, Badache M. 2013)

Solar air collector with fins or baffles, in vertical or horizontal passages (Foued Chabane 2013, Badache M. 2013) 


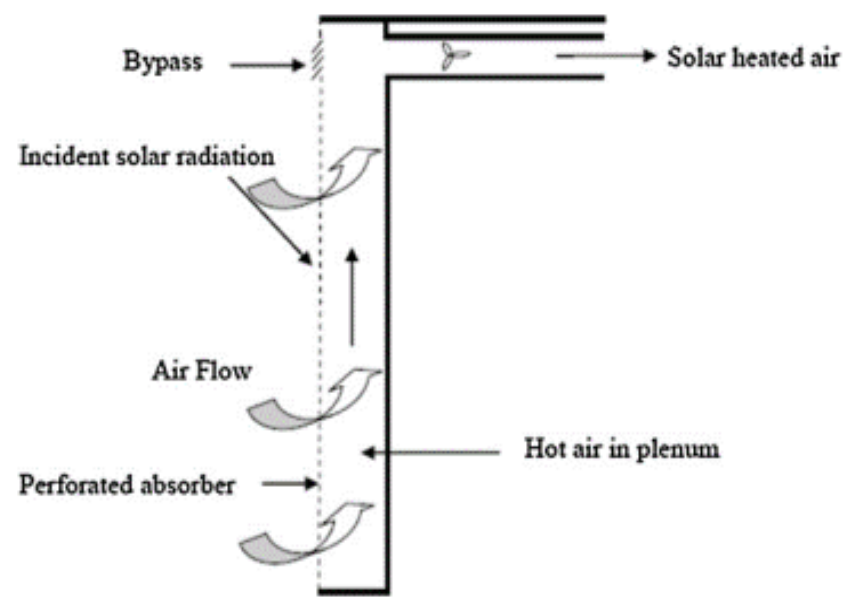

Fig. 5: Colector solar perforat fără geam (Shukla A. et al. 2012)

Schematic of standalone transpired solar air collector(Shukla A.et al. 2012)

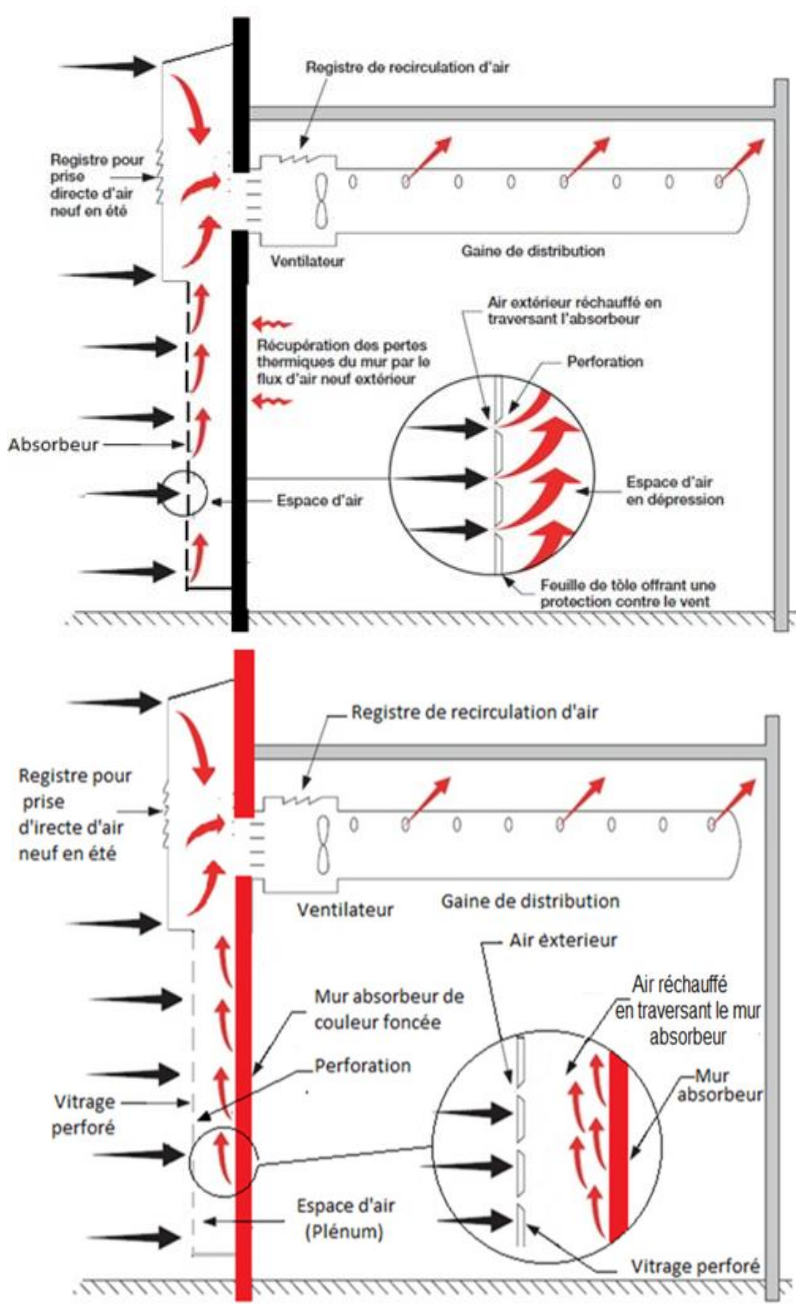

Fig. 6: Colector solar de aer cald cu material absorbant perforat metalic (a) sau polimer transparent (b) Solar air collector with perforated metal sheet (a) or transparent polymer-based collector (b) (http://www.retscreen.net/ang/news.php) 


\section{Performanțe ale colectoarelor termice cu sau fără geam, compacte sau perforate}

In alte lucrări (Ciocanea A. et.al 2011, Budea S. 2014) autorii compară două soluții constructive de colectoare solare, o variantă comercială cu materialul absorbant din aluminiu şi caneluri verticale şi un alt colector cu multiple treceri ale aerului prin colector constând dintro sită fină, deasă, metalică. Prima variantă a fost mai bună în privința randamentului, dar al doilea colector a oferit o stocare mai bună a căldurii.

Shukla A. et al.(Shukla A. et al. 2012) calculează randamentul colectorului solar pentru diferite debite de aer (Fig. 7), diferite radiații solare și viteze ale vântului (Fig.8) pentru un colector de aer perforat. Budea S. în 2014 (Budea S. 2014) analizează relația între radiaţia solară globală, temperatura aerului și viteza vântului pentru un colector solar cu geam, cu caneluri verticale și trecere mixtă, ca în Fig.9.

O relaţie propusă de Shukla A. et al. (Shukla A. et al. 2012) pentru randamentul unui colector perforat de aer este (1):

$$
\eta=\frac{\propto}{\left[1+\left(\frac{n_{Y}}{g}\right)+\frac{n_{C}}{\rho \varepsilon_{V} V}\right.}
$$

unde $\varepsilon$ este eficiența schimbului de căldură, $\alpha$ este coeficientul de absorbție, $h$ coeficientul de transfer de căldură radiativă $\left(\mathrm{W} / \mathrm{m}^{2} \mathrm{~K}\right), C v$ este coeficient specific de căldură, $v$ viteza vântului $(\mathrm{m} / \mathrm{s}), \rho$ densitatea aerului $(\mathrm{kg} / \mathrm{m} 3)$.

Cercetările privind colectoarele de aer fără geam pot oferi informații utile pentru proiectanți. Christophe Genevès (Genevès C. et.al. 2012) recomandă ca parametri: viteza minimă la aspirație $(0.04 \mathrm{~m} / \mathrm{s}$ în găurile supuse la vânt la colectoare perforate), orientarea (sud în emisfera nordică), absorbție radiativă mare, emisivitate mică, temperatura peste $40^{\circ} \mathrm{C}$, viteza vântului (sub $7 \mathrm{~m} / \mathrm{s})$, presiune minimă la aspirație $(25 \mathrm{~Pa})$.

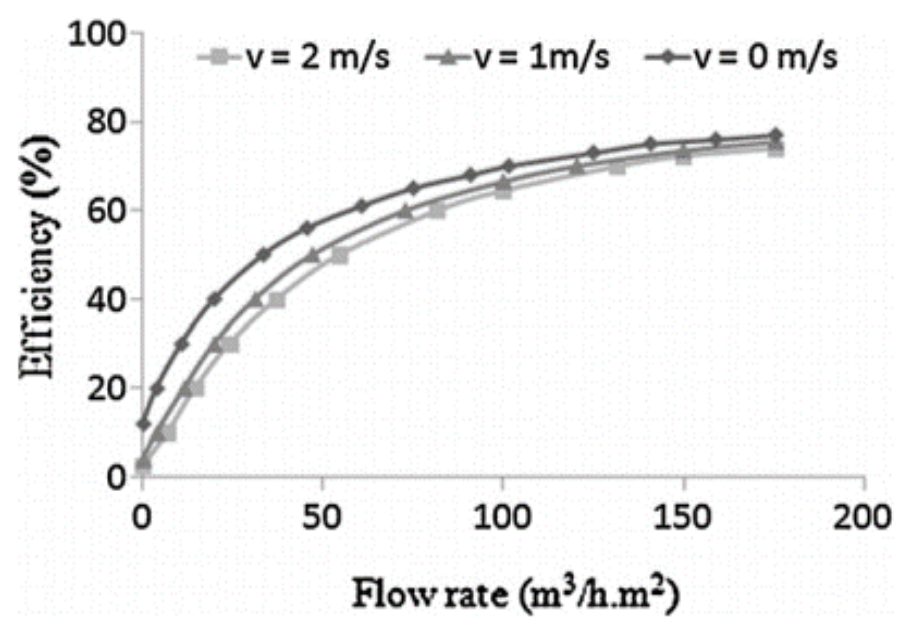

Fig. 7: Randamentul colectoarelor solare perforate la diferite viteze ale vântului The efficiency of transpired solar air collector with the flow rate variation (Shukla A. et al. 2012) (Shukla A. et al. 2012) 


\section{Performances of thermo-solar collector glazed or unglazed, compacts or transpired}

In another paper (Ciocanea A. et.al 2011) the authors compare two constructive solutions of solar air collector, one collector was a commercial collector with the absorber made of aluminum and vertical flow passages and the other collector was a through-pass air collector with the absorber consisting in a wire net made of soft steel. The first solution was better regarding the efficiency, but the second collector offered a higher heat storage time.

Shukla A. et al. (Shukla A. et al. 2012) calculated the efficiency of solar air collector for different air flow rates (Fig. 7), different solar global irradiation and wind speeds values (Fig.8) for a transpired air collector. Another research (Budea S. 2014)analyzed the relationship between the solar global irradiation, the air temperature and the wind speeds, for a glazed solar collector with mixed vertical passage, as in Fig.9.

A relation for the transpiredsolar collector efficiency is given by Shukla A. et al. (Shukla A. et al. 2012):

$$
\eta=\frac{\propto}{\left[1+\left(\frac{h_{r}}{g}\right)+\frac{h_{C}}{\rho c_{V} v}\right.}
$$

where $\varepsilon$ is heat exchange effectiveness, $\alpha$ is the absorptivity, h heat transfer coefficient $\left(\mathrm{W} / \mathrm{m}^{2}\right.$ $\mathrm{K})$, radiative or collector, $C v$ specific heat capacity, $v$ wind speed $(\mathrm{m} / \mathrm{s}), \rho$ density of air $(\mathrm{kg} / \mathrm{m} 3)$.

The unglazed thermo-solar air collector investigation can provide overall guidelines for the designer. Christophe Genevès in (GenevèsC. et.al. 2012)recommend the following parameters: minimum suctions speed $(0.04 \mathrm{~m} / \mathrm{s}$ in the hole for unglazed transpired collectors), orientation (south in the north hemisphere), a higher radiative absorption, low emissivity, temperature above $40^{\circ} \mathrm{C}$, wind condition (under $7 \mathrm{~m} / \mathrm{s}$ ), minimum aspiration pressure $(25 \mathrm{~Pa}$ ).
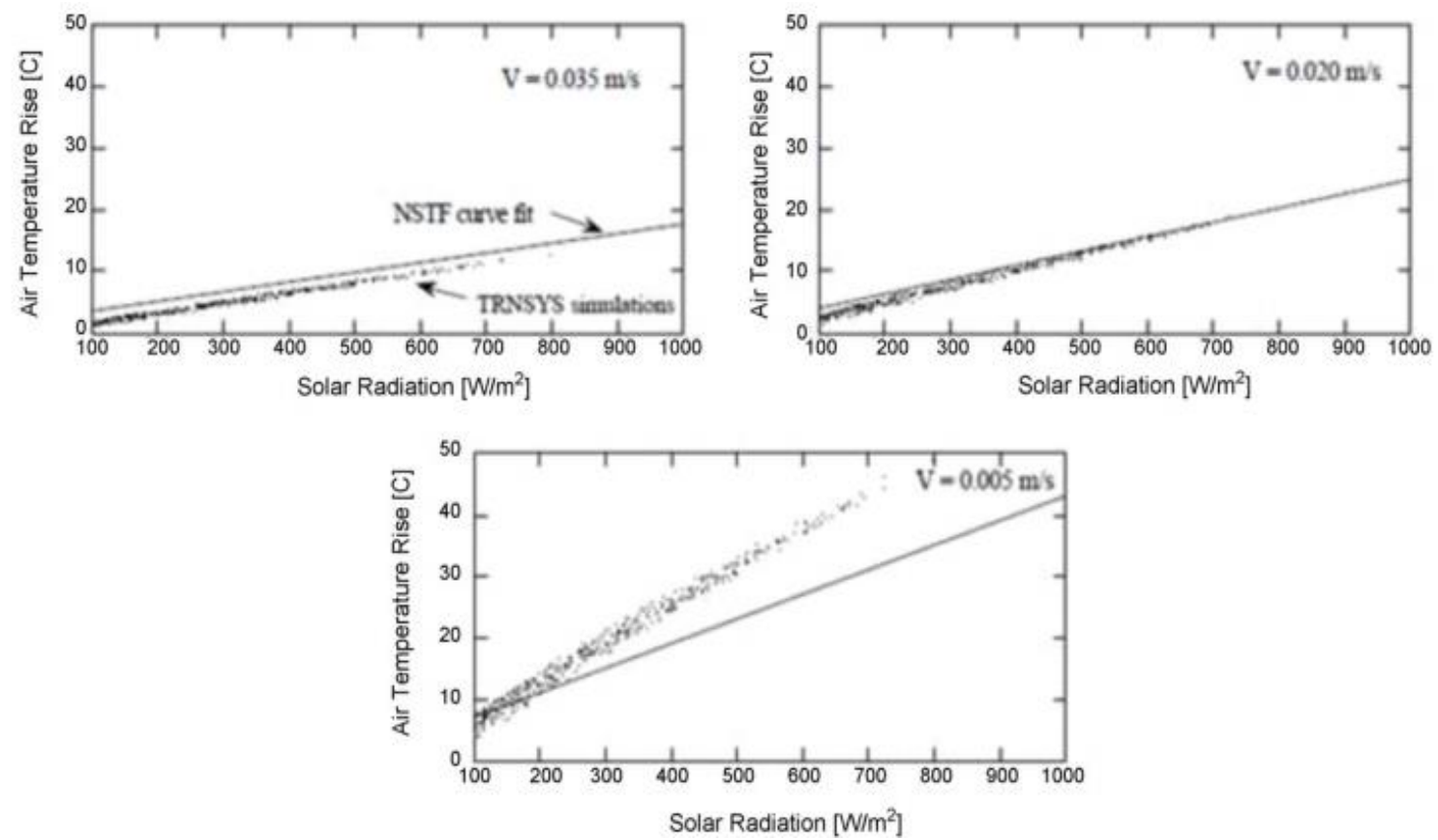

Fig. 8: Temperatura aerului în funcţie de radiaţie la diferite viteze ale aerului (Shukla A. et al. 2012) Air temperature versus solar irradiaion for different air speeds (Shukla A. et al. 2012) 


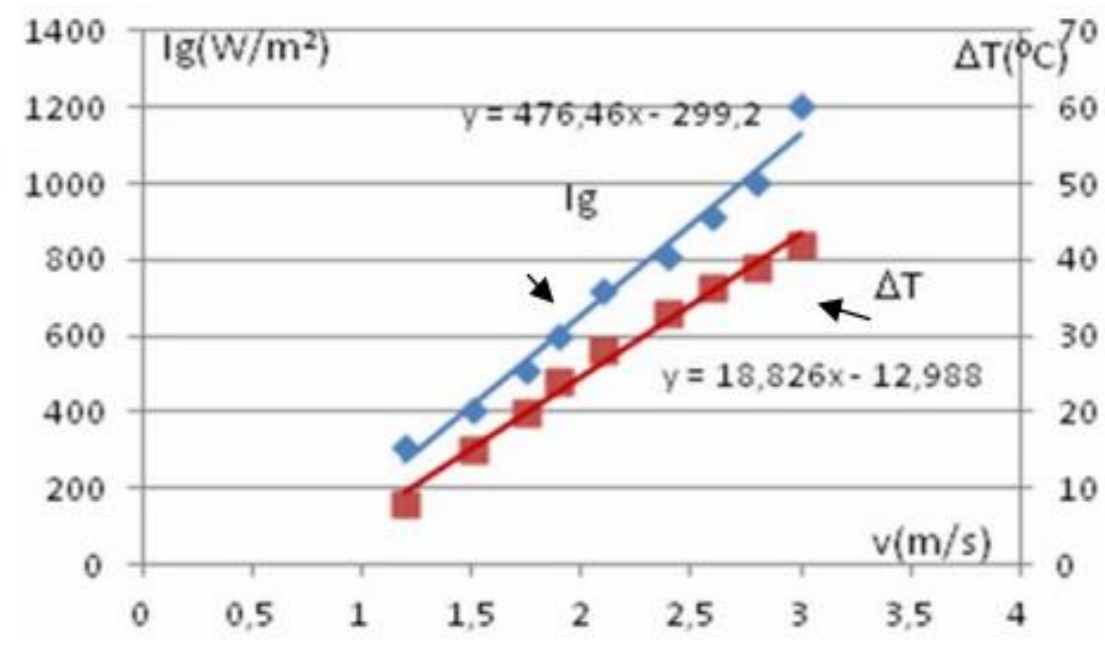

Fig. 9: Radiaţia solară şi temperatura aerului cald în funcţie de viteza aerului (Budea S. 2014) Solar global irradiance and temperature variations with the wind speed (Budea S. 2014)

Fleck B. A. et al. în (Fleck B. A. et al 2002) au studiat variația randamentului colectoarelor perforate cu radiația solară și cu viteza vântului - a se vedea Fig. 10, observând un vârf de randament la aproximativ $1.5 \mathrm{~m} / \mathrm{s}$.

Performanțele colectoarelor perforate depind de mai mulți parametri: diametrul găurii, aranjarea, spațiul dintre găuri, grosimea geamului, înălţimea colectorului, porozitatea. Cum se poate observa, un randament bun al colectoarelor perforate este de 50-60\%.

\section{Sisteme hibride cu colectoare de aer cald și panouri fotovoltaice}

Summer et al (Summers DN. et al. 1996, Summers DN. 1995) au arătat că din punct de vedere economic, colectoarele solare de aer fără geam și sistemele fotovoltaice sunt competitive dacă produc concomitent și căldură și electricitate. Acestea sunt recomandate pentru clădiri de birouri și clădiri noi.

Brunger în raportul IEA (Brunger AP. 1999), a descris urmărirea mai multor instalații cu colectoare fără geam și instrumentele de proiectare software. El a prezentat cu detalii rezultatele cercetărilor efectuate la Laboratorul Național de Energii Regenerabile (SUA) și la Laboratorul de Cercetări Termice Solide (Canada). Rezultatele principale arată impactul aspirației distribuite, efectul aerului preîncălzit, impactul vântului asupra colectoarelor fără geam. Informații similare pot fi găsite în (Christensen C. 1998, Gaberson H. 1999). Acestea au fost mai orientate spre clădiri de instituții în domeniul construcțiilor din SUA pentru utilizările colectoarelor de aer cald fără geam.

Mai mult, aplicațiile relativ noi, combină colectoarele de aer cald cu panourile fotovoltaice, ca o nouă tendință a evoluției utilizării energiei solare în cogenerare. Ar trebui efectuate în acest domeniu mai multe experimentări.

Guillermo Quesada, et.al. în lucrarea (Quesada G. 2012) grupează colectoarele de aer perforate și sistemele fotovoltaice în următoarele cinci categorii: solare termice, fotovoltaice , combinate termice și fotovoltaice, pereți de stocare a energiei termice și horn solar. Sistemele termice integrate in clădiri au tehnologie simplă. La acestea mai trebuie studiat efectul vântului. 


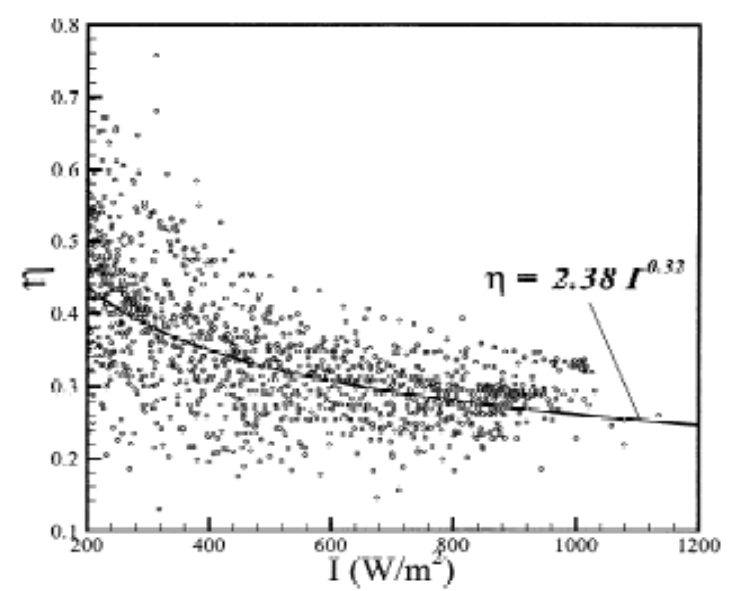

(a)

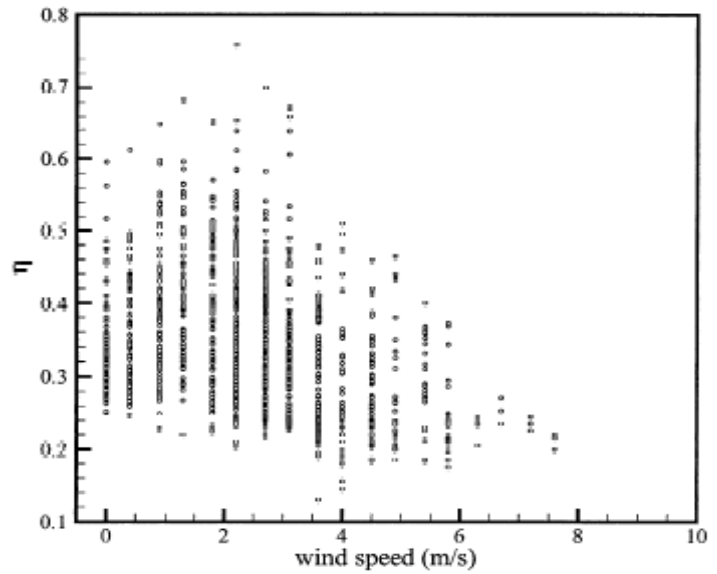

(b)

Fig. 10: Randamentul colectoarelor solare perforate în funcţie de radiaţia solară (a) şi viteza vântului (b) Transpired solar air collector efficiency vs solar irradiation (a) and wind speed (b)

(Fleck B. A. et al, 2002)

Fleck B. A. et al. in (Fleck B. A. et al 2002) studied the variation of the efficiency of the transpired thermo-solar collectorwith solar irradiation and wind speeds.As it can see in Fig. 10, results a peakof efficiency at roughly $1.5 \mathrm{~m} / \mathrm{s}$ wind speed.

The performance of a transpired thermo-solar collector depends on many parameters: hole's diameter, arrangement of holes, pitch spacing, plenum thickness, thickness of glazing, height of the collector, porosity. As can be seen, good efficiency of thermo-solar collectorsare between $50-60 \%$.

\section{Hybrid systems with thermal and photovoltaic solar collectors}

Summer et al (Summers DN. et al. 1996, Summers DN. 1995) have shown that from an economic point of view, thermo - solar collectors and photovoltaic systems are competitive if they produce both heat and electricity. The unglazed thermo-solarcollector was still recommended for large residential and office buildings and for new buildings.

Brunger in its report of IEA (Brunger AP. 1999), described the follow-up on several large unglazed collector installations and software design tools. He presented with details results of research conducted at National Renewable Energy Laboratory (USA) and at Solar Thermal Research Laboratory (Canada). Main results show the impact of distributed suction, the effect of pre-heated air, the wind impact on unglazed solar collector. Similar information can be found in (Christensen C. 1998, Gaberson H. 1999). Those were more oriented for federal building managers in the USA for unglazed solar collectors uses.

Moreover, relatively new applications, combine unglazed solar collectors and photovoltaic systems, as a new trend in the evolution of the use of solar energy in cogeneration. Several experiments should be carried out in this area.

Guillermo Quesada,et.al. in (QuesadaG. 2012) grouped thermal air collector and photovoltaic systems into the following five categories: "building-integrated solar thermal, building-integrated photovoltaic, building-integrated photovoltaic thermal, thermal storage 
Panourile fotovoltaice integrate in clădiri oferă multe avantaje. Ele pot aduce un aport de energie semnificativ pentru consumul intern al clădirilor. În plus, în anumite configurări panourile fotovoltaice pot reduce semnificativ sarcina de răcire / ventilare a spaţiilor din clădiri. De asemenea, aerul din spatele panourilor fotovoltaice răcește panourile și le mărește randamentul, asigurând și microclimatul clădirii. Sistemele hibride termice și fotovoltaice combină avantajele celor două sisteme prin integrarea lor în clădiri. Extragerea căldurii prin componenta termică, mărește randamentul panoului fotovoltaic. Acest efect combinat îmbunătățește în mare măsură sistemul fotovoltaic prin adăugarea puterii termice la puterea electrică. Pentru stocare, cel mai dezvoltat sistem este peretele de stocare termică care, în mod consecvent are o eficiență de (50-60\%). Tehnologia este suficient de avansată și există un standard european și internaţional UNE-EN ISO 13790 pentru a efectua calcule care descriu comportamentul termic al sistemelor solare (Quesada G. 2012).

Sistemele hibride por fi integrate în arhitectura clădirii pe pereți verticali sau pe acoperiș, ca în Fig. 11 și Fig.12 a,b,c, în Marea Britanie, Austria și respectiv China.

Sistemele hibride au randamente îmbunătățite cu 7-17\% după cum este indicat în lucrarea (Adnan Ibrahim, Ahmad Fudholi et.al. 2014). În Fig. 13 este reprezentată variaţia în timp a randamentului colectoarelor solare, iar in fig.14 performanțele termice și electrice în doua cazuri: cu și fără umbrire.

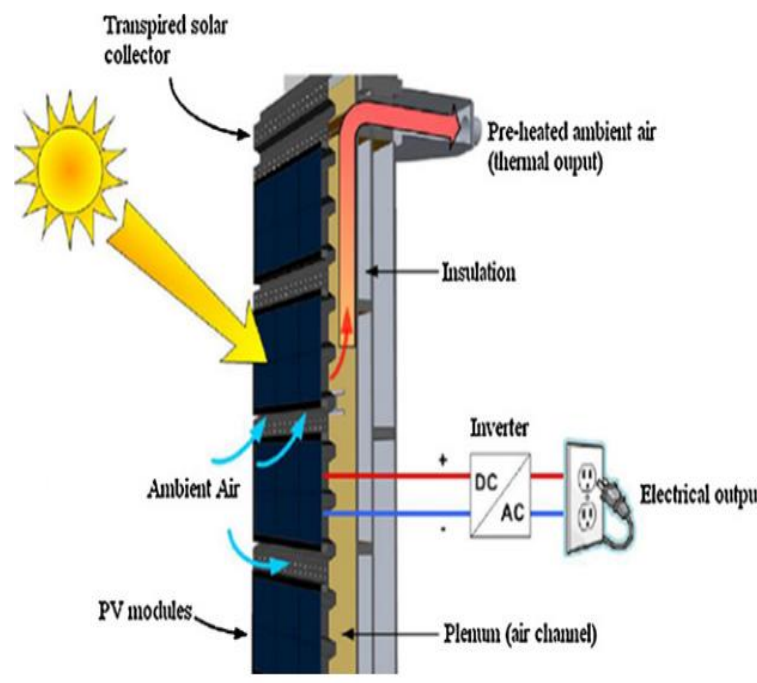

a)

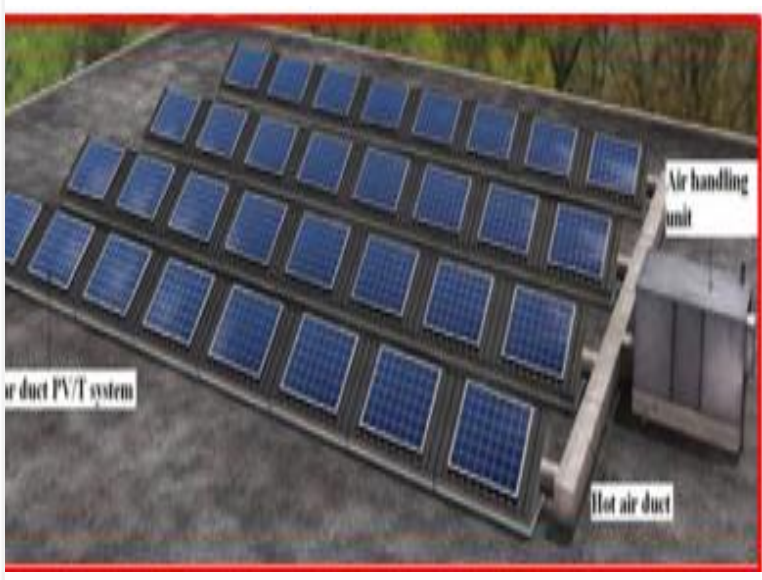

b)

Fig. 11: Integrarea în clădire a colectoarelor termo-solare şi fotovoltaice, pe perete vertical (a) şi pe acoperiş (b)

Build integrated of photovoltaic and thermal air collectors on vertical wall (a) and on the roof (b)

(A. Shukla et al. 2012, http://solarwall.com/en/products/solarwall-air-heating/solarduct.php.) 
wall and solar chimney. Building-integrated solar thermal technology certainly presentsan interest since it is a relatively simple technology. Still it is notyet fully optimized. For example, the impact of wind is not yet well understood. Building-integrated photovoltaic offers many advantages. They can produce a significant amount of energy, which in the best conditions can even exceed the buildings internal consumption. In addition, in certain configurations, photovoltaic panels can significantly reduce the cooling / ventilation of buildings in buildings. Also, the air behind photovoltaic panels cools the panels and increases their efficiency, ensuring the building's microclimate. Hybrid thermal and photovoltaic systems combine the benefits of both systems by integrating them into buildings. Extracting heat through the thermal component increases the efficiency of the photovoltaic panel. This combined effect greatly improves the photovoltaic system by adding thermal power to electrical power. The most developed system is the thermal storage wall and its variants, with an efficiency of (50-60\%) consistently. The technologyis advanced enough that a European and International Standard UNE-EN ISO 13790 exist, to perform calculations describing their thermal behavior" (QuesadaG. 2012).

Hybrid systems can be integrated in the building architecture on vertical wall or on the roof, like in Fig. 11 and Fig.12 a, b, c, in UK, Austria and China respectively.

Regarding the performances of the hybrid system with solar air collector and photovoltaic collector, an increase of 7-17\% of the efficiency is indicated in paper (Adnan Ibrahim, Ahmad Fudholiet.al. 2014). In Fig. 13 is illustrated time variation of the efficiency. Fig. 14 shows the thermal and electric performances in two cases: with and without shading.

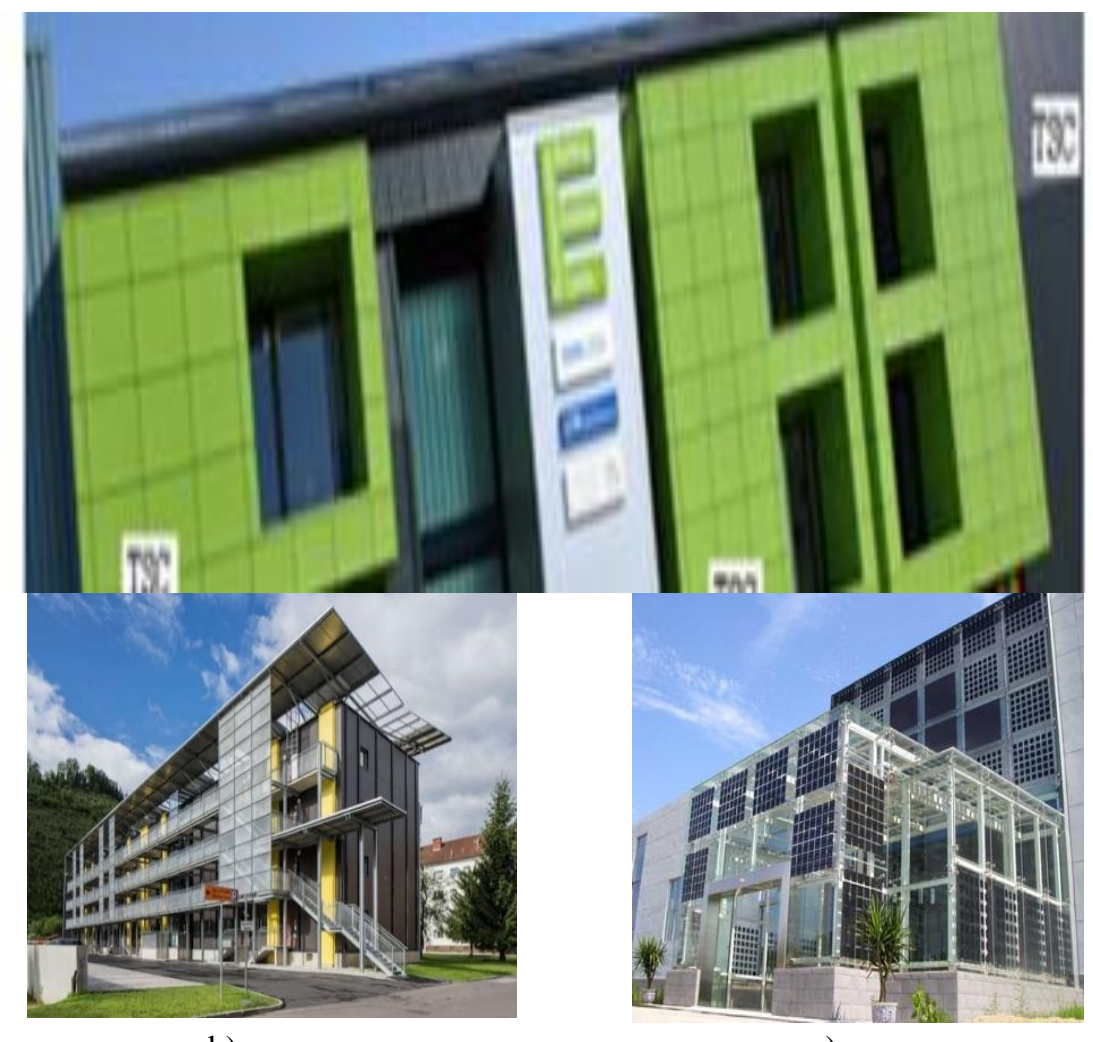

b)

c)

Fig. 12: a) Colectoare solare perforate la clădirea SBEC, TATA Steel, Shotton works, UK

Transpired thermal collector at SBEC building, TATA Steel, Shotton works, UK

b) http://www.buildup.eu/en/practices/cases/plusenergy-building-renovation-prefabricated-thermal-facadeelements-kapfenberghttp://www.buildup.eu/mt/node/45373

c) http://www.climatetechwiki.org/sites/climatetechwiki.org/files/images/extra/solar_bipv.jpg 


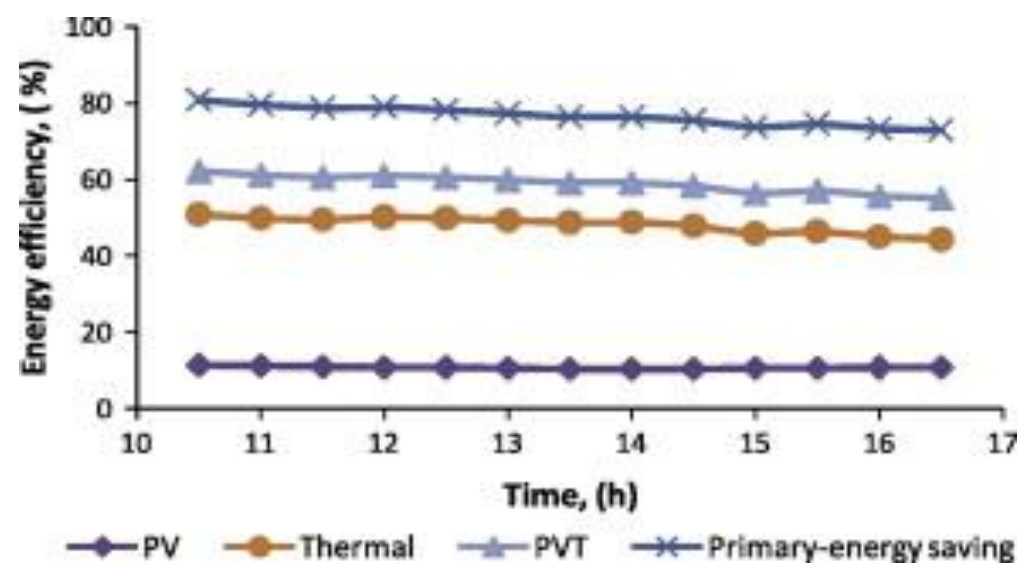

Fig. 13: Randamentul unui sistem hibrid TTC-PV (Adnan Ibrahim, Ahmad Fudholi s.o 2014)

The efficiency of a hybrid system with solar air collector and photovoltaic collector (Adnan Ibrahim, Ahmad Fudholi,2014)

\section{Materiale cu schimbare de fază pentru păstrarea performanțelor termice}

Spre deosebire de metode convenționale de stocare termică, materialele cu schimbare de fază (PCM) oferă densități de stocare a energiei mult mai mari, iar căldura este stocată și eliberată la o temperatură aproape constantă. Materialele cu schimbare de fază pot fi utilizate atât pentru sistemele de încălzire și de răcire active, cât și pentru cele pasive. În sistemele pasive, pot fi încapsulate în materiale de construcție, cum ar fi beton, plăci de ghips, în tavan sau podea pentru a crește capacitatea lor de stocare termică.

Alternativ, o unitate de stocare termică care utilizează materiale cu schimbare de fază, poate fi utilizată cu sisteme convenționale de încălzire și răcire a spațiului activ pentru a îmbunătăți eficiența termică globală, precum și pentru a reduce sarcina electrică de încălzire și de răcire.

O posibilitate interesantă în aplicațiile de construcție este integrarea materialelor cu schimbare de fază în materiale de construcție poroase pentru a mări masa termică. Plăcile de perete cu materiale cu schimbare de fază ar putea economisi până la $20 \%$ din costurile locuinței (Frank Bruno 2004).

O problemă cu încorporarea materialelor cu schimbare de fază în anvelopa clădirii constă în aceea că este dificil să se realizeze un transfer mare de căldură între aer și acestea.

Materialele cu schimbare de fază absorb cantităti mari de căldură la o temperatură aproape constantă. Acestea continuă să absoarbă căldura fără o creștere semnificativă a temperaturii până când tot materialul este transformat în faza lichidă. Ele stochează de 5 până la 14 ori mai multă căldură pe unitate de volum decât materialele convenționale de depozitare, cum ar fi apa, zidăria sau roca. Există materiale organice (parafina $(\mathrm{CnH} 2 \mathrm{n}+2)$, carbohidrați și lipide derivate), anorganice-hidrați de săruri ( $\mathrm{MnH} 2 \mathrm{O})$, materiale higroscopice, sau materiale cu faze Solid-Solid. Aceste materiale modifică structura lor cristalină dintr-o configurație de rețea la alta la o temperatură fixă și bine definită, iar transformarea poate implica încălziri latente comparabile cu cele mai eficiente materiale cu schimbare de fază solide / lichide. Nu există nici o schimbare vizibilă în aspectul materialului cu schimbare de fază (altul decât o ușoară expansiune / contracție) și nu există probleme legate de manipularea lichidelor, adică de izolare, scurgeri etc. 


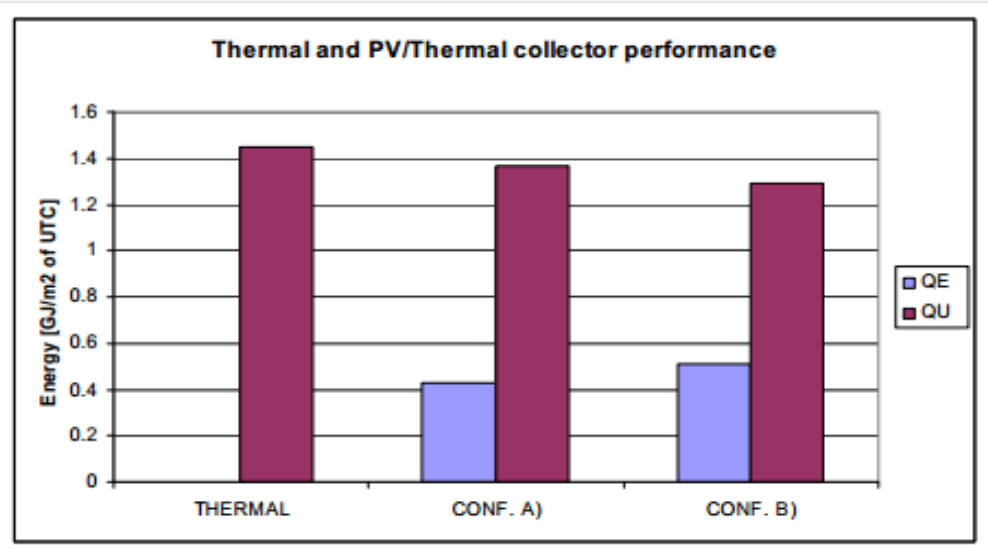

Fig. 14: Performanţele colectoarelor PV/Termice A) fără umbrire, B) cu efect de umbrire (Delisle Veronique 2008)

Thermal and photovoltaic/Thermal collector performance A) without shading effect, B) with shaded effect (Delisle Veronique 2008)

\section{Phase change materials for a good keeping of the thermal performance}

Unlike conventional sensible thermal storage methods, phase change materials (PCMs) provide much higher energy storage densities and the heat is stored and released at an almost constant temperature. Phase change materials can be used for both active and passive space heating and cooling systems. In passive systems, they can be encapsulated in building materials such as concrete, gypsum wallboard, in the ceiling or floor to increase their thermal storage capacity.

Alternatively, a thermal storage unit using phase change materials can be used with conventional active space heating and cooling systems to improve the overall thermal efficiency as well as to reduce the peak heating and cooling electrical load. Phase change materials can also be incorporated in conventional heating or cooling systems.

One interesting possibility in building applications is the impregnation of phase change materials into porous construction materials to increase thermal mass. Phase change materials wall board could save up to $20 \%$ of the house space conditioning costs (Frank Bruno 2004).

A problem with incorporating phase change materials in the building envelope is that it is difficult to exchange a high rate of heat between the air and these.

Phase change materials absorb large amounts of heat at an almost constant temperature. These continue to absorb heat without a significant rise in temperature, until all the material is transformed to the liquid phase. They store 5 to 14 times more heat per unit of volume than conventional storage materials such as water, masonry or rock. There are Organic materials (Paraffin $(\mathrm{CnH} 2 \mathrm{n}+2)$, carbohydrate and lipid derived), Inorganic phase change materials - Salt hydrates $(\mathrm{MnH} 2 \mathrm{O})$, Hygroscopic materials, or Solid-Solid Materials. These materials change their crystalline structure from one lattice configuration to another at a fixed and well-defined temperature, and the transformation can involve latent heats comparable to the most effective solid/liquid phase change materials. There is no visible change in the appearance of the phase change materials (other than a slight expansion/contraction) and there are no problems associated with handling liquids, i.e. containment, potential leakage, etc. 
Aceste materiale se pot executa dintr-o plasă de cupru imersată într-o ceară de parafină. Plasa de cupru din parafina poate fi considerată un material termo-compozit. Este importantă conductivitatea termică. Dacă materialul este lichid, structura solidă trebuie să fie poroasă. De asemenea, pot fi utilizate materiale compozite solide cum ar fi fibra de sticlă ( https://en.wikipedia.org/wiki/Thermal_energy_storage\#Solar_energy_storage).

Vakilaltojjar și Saman (2001) au studiat unități de stocare cu materiale cu schimbare de fază pentru încălzirea și răcirea spațiului, integrat cu un sistem de aer condiționat cu ciclu invers. Hüseyin și Aydın (2009) au analizat performanțele teoretice și experimentale ale materialului de schimbare a fazelor utilizate pentru a analiza comportamentul termic tranzitoriu al unității de stocare. Concluzia a fost că la colectorul solar de aer integrat cu materiale cu schimbare de fază s-a creat o diferență de temperatură mai mare cu 6-9 ${ }^{\circ} \mathrm{C}$ între interiorul și exteriorul clădirii, furnizând $18-23 \%$ din totalul necesarului de energie termică zilnică al unei clădiri verzi, în comparație cu dispozitivul de încălzire convențional.

Krishnananth și Murugavel (2012) au cercetat performanțele experimentale ale unui colector de aer cu dublă trecere și cu parafină și capsule de aluminiu. Ei au concluzionat că panoul solar de aer cu parafină a furnizat temperaturi mai ridicate de aer în timpul zilei datorită stocării, cu randament mai mare în orele de seară. Fatah (1994) a studiat performanțele unui colector solar de aer cu tuburi de cupru umplute cu materiale cu schimbare de fază cu temperaturi de topire de $51-43 \circ \mathrm{C}$. El a concluzionat că acest sistem a avut o performanţă bună, randamentul mediu zilnic a fost 26\% - 63\%.(Nkwetta, D. N. 2013).

Autorii acestui articol sunt în faza de testare experimentală a unui model de colector solar cu perforaţii, cu materiale cu schimbare de fază pe bază de parafină, intr-o structura de aluminiu.

\section{Aplicații software pentru analiza performanțelor colectoarelor solare}

Veronique Delisle, s.o în lucrarea (Delisle Veronique 2008) au arătat că mai multe modele matematice pentru colectoare termosolare fără geam au fost dezvoltate de-a lungul timpului pentru a ușura proiectarea lor. SWift și Retscreen sunt cele mai cunoscute și obțin rezultate similare, chiar dacă folosesc abordări destul de diferite (Carpenter et al., 2002). Principala diferență dintre cele două programe este aceea că SWift utilizează ecuații derivate din principiile fundamentale ale termodinamicii, cum ar fi legea lui Fourier, în timp ce Retscreen utilizează o corelație empirică.

Dymond și Kutscher (1995 și 1997) au lucrat pentru a dezvolta un model de calcul unde configurațiile geometrice pot fi variate și utilizate pentru a proiecta colectoare termo-solare. $\mathrm{Au}$ folosit un model de rețea de țevi. Modelul include toate mecanismele semnificative de transfer de căldură și patru variații de presiune în sistem: scăderea presiunii prin colector, frecarea în interiorul colectorului, scăderea presiunii în flotabilitate și scăderea presiunii de accelerare. Programul pe care l-au dezvoltat a fost numit TCFLOW - software pentru analiza curgerii în colectoare termice și a fost folosit de „Conserval Engineering” în proiectare. Pentru a valida modelul, au comparat rezultatele pentru viteza și temperatura suprafeței cu termografia digitizată a colectorului.

Summers (1995) cu aplicația TRNSYS - Transient System Simulation Tool, a creat un program de simulare utilizat în principal în domeniul ingineriei energiei regenerabile și al simulării clădirilor pentru proiectare solară pasivă sau activă. TRNSYS este un pachet software de simularea, comercial, dezvoltat la University of Wisconsin, pentru sistem de colector fără 
These materials can consist in a copper-mesh immersed in a paraffin-wax. The coppermesh within paraffin-wax can be considered a thermal-composite material. Important is their thermal conductivity. If the phase change material is required to flow, the solid must be porous, such as a mesh; Also, can be used solid composites such as fiber-glass usually refers to a fiber (of glass) and a matrix (the glue which solidifies to hold fibers and provide compressive strength (https://en.wikipedia.org/wiki/Thermal_energy_storage\#Solar_energy_storage).

Vakilaltojjar and Saman (2001) studied a storage unit with change materials systems, for space heating and cooling integrated with a reverse cycle air conditioning system. Hüseyin and Aydin (2009) have analyzed theoretical and experimental performance of phase change material employed to analyze the transient thermal behavior of the phase change materials storage unit. Conclusion was that the solar air collector integrated with phase change material created a differential temperature of $6-9 \circ \mathrm{C}$ between the inside and outside of the greenhouse, providing about $18-23 \%$ from the total daily thermal energy requirements of the greenhouse, in comparison with the conventional heating device.

Krishnananth and Murugavel (2012) investigated the experimental performance of a double-pass solar air collector integrated with paraffin storage with aluminum capsules. They concluded that the solar air heater with paraffin as storage delivered higher temperatures air throughout the day with higher efficiency recorded in the evening hours. Fatah (1994) researched the performance of a solar air collector integrated with an absorber made up of copper tubes filled with phase change materials with melting temperatures of $51-43{ }^{\circ} \mathrm{C}$. He concluded that this system showed better performance otherwise the daily average efficiency was $26 \%$ and $63 \%$ (Nkwetta, D. N. 2013).

\section{Dedicated software to analyze the performances of solar collectors}

Veronique Delisleet.al.in paper (Delisle Veronique2008) says that "several models of thermal unglazed collector were developed over the years, to facilitate their design. SWift and Retscreen are the most well-known ones and predict similar results even though they use quite different approaches (Carpenter S. et al., 2002). The main difference between the two programs is that SWift uses equations derived from basic thermodynamics principles such as Fourier's law, while Retscreen uses empirical correlation.

Dymond and Kutscher (1995 and 1997) worked to develop a computer model where geometric configurations could be varied and used to design collectors. They used a pipe network model. The model included all significant heat transfer mechanisms and four pressure drops in the system: pressure drop through the collector, friction inside the collector plenum, buoyancy pressure drop, and acceleration pressure drop. The program they developed was named TCFLOW - software to analyze the flowing through solar collector and was used by Conserval Engineering in the design of their collectors. To validate the model, they compared the results for surface velocity and temperature with digitized collector thermography.

Summers (1995) created a TRNSYS -Transient System Simulation Tool a simulation program primarily used in the fields of renewable energy engineering and building simulation for passive as well as active solar design. TRNSYS is a commercial software package developed at the University of Wisconsin simulation of an unglazed system based upon an empirical heat transfer from Kutscher. There are two models for transpired thermal collector computation: Kutscher and Van Decker. The TRNSYS application does not 
geam, bazat pe un transfer de căldură empiric. Există două modele pentru calculul colectoarelor solare termice: Kutscher și Van Decker (Maurer C.2004). Aplicația TRNSYS nu ține seama de stratificare aerului din încăpere. Efectul stratificării a fost studiat cu FLUENT. Arulandanam S.J.(1999) a folosit codul Computer Fluid Dinamic - CFD, pentru a determina eficiența schimbului de căldură pentru găurile circulare dispuse în colțurile unui pătrat. Modelul, totuși, nu a fost dezvoltat în condiții de vânt și nu a inclus transferul de căldură în spatele plăcii. O corelație pentru numărul Nusselt a fost găsită pe baza variabilelor non-dimensionale: pentru gaură- numărul Reynolds, porozitatea, grosimea plăcii adimensională şi un termen denumit admitanță plană (Maurer C.2004).

Figura 14 reprezintă o comparație între un sistem termo-solar standard și un sistem hibrid fotovoltaic/termic montate ca în configurațiile A) și B). Simularea a fost realizată pentru vremea din Toronto, cu TRNSYS software (Delisle Veronique 2008).

Foarte utilizată în analiza energetică și studiile de caz este aplicația Retscreen (Carpenter, S., Meloche N. 2002), ( http://trnsys.de/docs/komponenten/komponenten_standard_en.htm).

De câțiva ani, a fost dezvoltată o nouă aplicație COMSOL (https://www.comsol.com/subsurface-flow-module) cu modul dedicat pentru colectoarele solare perforate, cu modulul de curgere sub suprafață, pentru a simula fluxul de fluid în medii poroase, în care poate fi utilizată Legea lui Darcy, în funcție de dimensiunea porilor. Acest flux este conectat cu alte fenomene, cum ar fi poro-elasticitatea, transferul de căldură utilizând ecuațiile Navier-Stokes, inclusiv termeni care iau în considerare porozitatea mediilor și fluidului care circulă.

\section{Concluzii}

Problemele energetice și de mediu generate de poluare sunt foarte importante și urgente.

Eficiența energetică a clădirilor poate fi realizată prin optimizarea, controlul și automatizarea sistemelor cu colectoare termo-solare și hibride, cu panouri fotovoltaice, prezentate în acest articol. De interes major este şi integrarea acestor colectoare în arhitectura clădirilor și au fost date câteva exemple în acest sens.

Autorii au trecut în revistă diferite soluții constructive de colectoare solare termice, au arătat performanțele acestora și parametrii de care depind aceste performante, au integrat cercetările lor anterioare în acest domeniu în preocupările la nivel mondial.

Autorii își concentrează atenția pe colectoarele solare de aer cald cu perforații, fără geam, care includ și materiale cu schimbare de fază, model ce nu a fost încă experimentat în România. În comunicările ulterioare vor fi prezentate mai multe rezultate experimentale ale acestei cercetări.

\section{Acknowledgment}

Această cercetare este susținută prin programul UEFISCDI PN-III-P2-2.1-PED-2016-1154, contract 83PED/2017. 
take into account the room air stratification. The stratification effect can be studied with FLUENT application. Arulandanam S.J. (1999) used a Computer Fluid Dinamic - CFD code to determine the heat exchange effectiveness for circular holes on a square pitch. The model, however, was only developed under no wind conditions and excluding heat transfer at the back of the plate. A correlation for the Nusselt number was found based on the non-dimensional variables: for the hole, Reynolds number, porosity, non-dimensional plate thickness, and a term called plate admittance (Maurer, C.2004).

Figure 14 presents a comparison of the performance of a standard unglazed solar collector and of a photovoltaic / thermal collector mounted according to configuration A) and B). The simulations were performed with the weather data for the city of Toronto, with TRNSYS software (Delisle Veronique 2008).

Highly used in energy analyzes and case studies is the Retscreen application (Carpenter, S., Meloche N. 2002, (http://trnsys.de/docs/komponenten/komponenten_standard_en.htm).

From few years a new software was developed COMSOL (https://www.comsol.com/subsurface-flow-module) with dedicated module for transpired thermal collector, with the subsurface flow module, to simulate fluid flow in porous media in which Darcy's Law can be used, depending on the size of the pores. This flow is connected with other phenomena, such as poro-elasticity, heat transfer using Navier-Stokes equations including terms that consider the porosity of the media and fluid flowing through.

\section{Conclusion}

The two major energy consumers and pollution generators are: urban, office or industrial buildings and transports.

Energy and environmental issues are very important and urgent.

Energy efficiency of buildings can be achieved by optimizing, controlling and automating solar air collectors and hybrid PV systems reviewed in this article. Of major interest is the integration of these collectors into the building architecture and some examples has been given.

The authors reviewed the various constructive solutions of thermal solar collectors, showed their performance and the parameters on which these performances depend, integrated their previous research in this field into global concerns.

The authors focus their attention on the solar air, unglazed solar collectors, which also include phase-changing materials, a model not yet studied in Romania. Further experimental results of this research will be presented in subsequent communications.

\section{Acknowledgment}

This research is supported by UEFISCDI PN-III-P2-2.1-PED-2016-1154, contract 83PED/2017. 


\section{Referinţe/References}

Shukla, A. et al. (2012), A state of art review on the performance of transpired solar collector, Renewable and Sustainable Energy Reviews, 16 (2012), 3975-3985.

Foued Chabane, Noureddine Moummi, Said Benramache. (2013), Experimental analysis on thermal performance of a solar air collector with longitudinal fins in a region of Biskra, Algeria, Journal of power technologies, 93(1), 52-58.

Badache, M. (2013), Étudenumerique et experimentale du transfer de chaleurdans un capteursolaire a perforation dote d'un collecteur transparent et opaque, These par articles presentee a l'Écolede TECHNOLOGIE SUPÉRIEURE, MONTRÉAL, le 30 AOÛT 2013.

Ciocănea, A., DragomirescuA., BudeaS. (2011), Experimental Research on Transient Regimes of Solar Air Heat Collectors, Environmental Engineering \& Management Journal (EEMJ) 10 (8), 1097-1103.

Genevès, C., Rousse D., Hallé, S., Dutil1,Y., Quesada, G.(2012).

Review of Unglazed Transpired Collectors (UTCs), Technologies of energy and energy efficiency (t3e) industrial research chair, Dept. Mechanical Engineering, École de technologiesupérieure, Université du Québec, 1100, rue Notre-Dame, ouest, Montréal, H3C 1K3, Canada, 2012.

Budea, S. (2014), Solar Air Colector for Space Heating and Ventilation Applications Performance and Case Studies in Romania Climatic Conditions, Energies 7/2014, 37813792.

Fleck, B. A. et al.(2002), A field study of the wind effects on the performance of an unglazed transpired solar collector, Solar Energy 73(3), 209-216.

Summers, D.N.(1996), Mitchell JW, Klein SA, Beekman WA. Thermal simulation and economic assessment of unglazed transpired collector systems. In: CampbellHowe R, WilkinsCrowder B, editors. Solar '96 - the 1996 American Solar Energy Society Annual Conference, Proceedings Of1996. 112-7.

Summers, D.N.(1995). Thermal Simulation and Economic Assessment of Unglazed Transpired Collectors Systems. M.S. Thesis, University of Wisconsin at Madison, Madison, WI.

Brunger, AP.(1999), Low cost, high performance solar air-heating systems using perforated absorbers. Solar Heating and cooling program IEA; 1999.

Christensen, C.(1998), Transpired Collectors (Solar Preheaters for Outdoor Ventilation Air). In: Program FEM, editor.1998.

Gaberson, H. (1999), Do T. Solar Preheated Ventilation - Innovative Solar Technology. In: CA NFESCPH, editor.

Quesada G., Rousse,D., Dutil,Y., Badache,M., Halle,S.(2012), A comprehensive review of solar facades. Opaque solar facades, Renewable and Sustainable Energy Reviews 16 (2012)2820- 2832.

Adnan Ibrahim, Ahmad Fudholis.o.(2014), Efficiencies and improvement potential of building integrated photovoltaic thermal, Energy Conversion and Management, 77, January 2014, 527-534.

Bruno Frank Ph.D. (2004), Using Phase Change Materials (PCMs) for space heating and cooling in buildings, Sustainable Energy Centre, University of South Australia the 2004 AIRAH performance enhanced buildings environmentally sustainable design conference. 
Nkwetta, D. N., Haghighat, F.(2013), Thermal energy storage with phase change material-A state-of-theart review. Sustainable Cities and Society, http://dx.doi.org/10.1016/j.scs.2013.05.007.

Delisle Veronique, CollinsM.R. (2008), Model of a PV/Thermal Unglazed transpired solar collector, Conference Paper . April 2008, https://www.researchgate.net/publication/268047106.

Maurer C.(2004), Field study and mondeling of an unglazed transpired solar collector system,A thesis of Master of Science Graduate Faculty of North Carolina State University, Mechanical and Aerospace Eng.Raleigh.

Carpenter, S., Meloche N. (2002), The Retscreen Model for Simulating the Performance of Solar Air Heating Systems, Proceedings of e-sim 2002.

\section{Referinţe web/Web references}

https://en.wikipedia.org/wiki/Solar_thermal_collector\#Solar-thermal_collectors_heating_air. http://www.fao.org/docrep/t1838e/T1838E0v.htm

http://rimstar.org/renewnrg/solar_air_heater_types_diy_homemade.htm

Comparing Solar Air Heater Designs \& Performance in Home Energy, http://stonehavenlife.com/comparing-solar-air-heater-designs-performance/

Retscreen (2012), http://www.retscreen.net/ang/news.php

http://solarwall.com/en/products/solarwall-air-heating/solarduct.php.

http://www.buildup.eu/en/practices/cases/plusenergy-building-renovation-prefabricatedthermal-facade-elements-kapfenberg

http://www.buildup.eu/mt/node/45373

http://www.climatetechwiki.org/sites/climatetechwiki.org/files/images/extra/solar_bipv.jpg https://en.wikipedia.org/wiki/Thermal_energy_storage\#Solar_energy_storage

http://trnsys.de/docs/komponenten/komponenten_standard_en.htm

https://www.comsol.com/subsurface-flow-module 